\title{
Evaluation of Low Cost-Activated Carbon Produced from Waste Tyres Pyrolysis for Removal of 2-Chlorophenol
}

\author{
Kanchana Manirajah, Sheela V. Sukumaran, Nornasuha Abdullah, Hazirah A. Razak, Nurul \\ Ainirazali* \\ Faculty of Chemical \& Natural Resources Engineering, Universiti Malaysia Pahang, \\ Lebuhraya Tun Razak, 26300 Gambang, Kuantan, Pahang, Malaysia
}

Received: 15 th November 2018; Revised: th $^{\text {th }}$ February 2019; Accepted: $8^{\text {th }}$ February 2019; Available online: 30th April 2019; Published regularly: 1st August 2019

\begin{abstract}
A low cost Activated Carbon (AC) was prepared by using waste tyres as raw material for the removal of 2-chlorophenol (2-CP). The AC adsorbent was prepared and activated by pyrolysis process at $900{ }^{\circ} \mathrm{C}$ under constant nitrogen flow. The physical properties of the AC produced was characterized using X-ray Diffraction (XRD), Brunauer-Emmett-Teller (BET), Field Emission Scanning Electron Microscopy (FESEM), and Fourier Transform Infra Red (FTIR). The influence of initial adsorbate concentration, $\mathrm{pH}$ and adsorbent dosage on the removal of 2 - $\mathrm{CP}$ in the batch-operational mode at ambient temperature were also investigated. The results obtained showed the $\mathrm{AC}$ presence of an amorphous carbon with high BET surface area and a total pore volume of $208 \mathrm{~m}^{2} \cdot \mathrm{g}^{-1}$ and $0.5817 \mathrm{~cm}^{3}$, respectively. The highest adsorption capacity of 2-CP by the AC absorbent was achieved at an initial concentration of 10 $\mathrm{mg} . \mathrm{L}^{-1}, \mathrm{pH} 5$, and adsorbent dosage of $0.5 \mathrm{~g}$ in the first $10 \mathrm{~min}$ of contact time. This finding proves that the low cost-AC produced from waste tyres can be utilized for an effective removal of chemical plant wastewater containing toxic chlorine substances. Copyright (C) 2019 BCREC Group. All rights reserved
\end{abstract}

Keywords: Waste tyre; Activated Carbon; Adsorption; 2-Chlorophenol; Pyrolysis

How to Cite: Manirajah, K., Sukumaran, S.V., Abdullah, N., Razak, H.A., Ainirazali, N. (2019). Evaluation of Low Cost-Activated Carbon Produced from Waste Tyres Pyrolysis for Removal of 2Chlorophenol. Bulletin of Chemical Reaction Engineering \& Catalysis, 14(2): 443-449 (doi:10.9767/bcrec.14.2.3617.443-449)

Permalink/DOI: https://doi.org/10.9767/bcrec.14.2.3617.443-449

\section{Introduction}

Most phenolic compounds including 2chlorophenol (2-CP) are categorized as a major pollutant to human being due to its high toxicity even at low concentration [1]. The 2-CP has also been categorized as an aquatic pollutant as its has been discovered that it is being released to the surrounding via anthropogenic activities.

\footnotetext{
* Corresponding Author.

E-mail: ainirazali@ump.edu.my (N. Ainirazali);

Telp: +60-9-5492833, Fax: +60-9-5492889
}

Continuous discharge of 2-CP will ultimately have a negative impact to the aquatic ecosystem [2]. Humans who were exposed to high concentration of 2-CP developed adverse effects, such as: dizziness, loss of nervous system, decrease in capability, difficult in focusing, and irregular heartbeat $[2,3]$. Therefore, it is necessary to treat the wastewater containing phenolic compounds before its being released to the river and environment.

Various process, such as: adsorption [4] catalytic wet oxidation [5], biodegradation [6], ozonation, and electrochemical degradation [7], have been studied regarding treatment of waste 
water containing chlorophenol. Among all the studied process, adsorption technology for treatment of chlorophenol was well-agreed as the most significant technique. This is due to the fact that properties and types of material that were being used as adsorbent plays a crucial role to achieve high chlorophenol removal.

AC was commonly produced by pyrolysis process and is widely used for industrial scale as an adsorbent especially for purification or separation of liquid and gases $[4,8,9]$. AC also has been proven to be an effective adsorbent mainly for organic and inorganic compounds due to its large surface area of $3000 \mathrm{~m}^{2} \cdot \mathrm{g}^{-1}$, defined porosity, and its unique chemical properties [10]. The porous structure of AC provides a network of interconnected macropores, mesopores, micropores that enhances the capacity for the adsorption of the organic molecules. However, commercial AC requires high production costs which tends to be more expensive compare to other adsorbent. Therefore, materials rich in carbon content, such as: tyres, which can be found abundantly as waste materials can be used as an alternative source to produce AC. This can be considered as a green approach, since it can reduce the cost of raw material, eliminate fire hazard and addresses solution related to the disposal of pollutant waste tyres $[10,11]$. In this contribution, problematic waste tyre was used as raw material in producing $\mathrm{AC}$ adsorbent for treatment of chlorine compound, focusing on the effects of process conditions on removal of 2 -chlorophenol.

\section{Materials and Methods}

\subsection{Materials}

Pure 2-chlorophenol (2-CP), hydrogen peroxide $\left(\mathrm{H}_{2} \mathrm{O}_{2}\right)$, potassium hydroxide $(\mathrm{KOH})$ and hydrochloric acid ( $\mathrm{HCl})$, purchased from SigmaAldrich. Waste tyre used in this study was taken from BS tyre shop located in Gambang, Pahang.

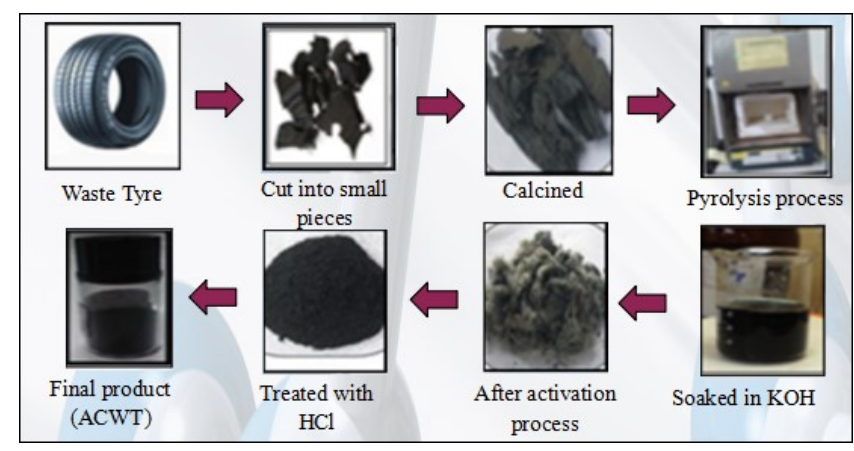

Figure 1. Schematic diagram for preparation of AC

\subsection{Preparation of AC Adsorbent from Waste Tyre}

Initially, the cleaned waste rubber tyre was cut to small granulates before being dried at $110{ }^{\circ} \mathrm{C}$ for $2 \mathrm{~h}$. The granules were then heated up to $300{ }^{\circ} \mathrm{C}$ in furnace for $3 \mathrm{~h}$ in order to produce black tire crude oil and distilled diesel oil. Next, the activations of char was done by placing it at into the pyrolysis reactor at $500{ }^{\circ} \mathrm{C}$ for $5 \mathrm{~h}$ with constant nitrogen flow of $200 \mathrm{~mL} \mathrm{~min}$ 1. The chars were then recovered from the pyrolysis reactor and was treated with hydrogen peroxide, $\mathrm{H}_{2} \mathrm{O}_{2}$ (6\% concentration) with carbon $/ \mathrm{H}_{2} \mathrm{O}_{2}$ ratio of $1 \mathrm{~g} 20 \mathrm{~m} . \mathrm{L}^{-1}$. The mixture was then placed in an oven and heated at $100{ }^{\circ} \mathrm{C}$ for $24 \mathrm{~h}$. The obtained sample was then washed thoroughly with deionized water and dried at $110{ }^{\circ} \mathrm{C}$ for $2 \mathrm{~h}$ to form activated carbon. Next, the activated carbon was soaked with $\mathrm{KOH}$ at $30{ }^{\circ} \mathrm{C}$ for $30 \mathrm{~min}$ with a weight ratio of $1: 3$ and then dried in oven at $60{ }^{\circ} \mathrm{C}$ for $2 \mathrm{~h}$. The activations were taken place at an activation temperature of $900{ }^{\circ} \mathrm{C}$ in the presence of $200 \mathrm{~mL} \cdot \mathrm{min}^{-1}$ nitrogen gas for $3 \mathrm{~h}$. Further modification of rubber tyre carbon in creating oxygen surface groups was done by acid treatment of $37 \mathrm{M}$ $\mathrm{HCl}$. The mixture of carbon and acid solution was stirred and heated at $100{ }^{\circ} \mathrm{C}$ for $24 \mathrm{~h}$. The resulted sample was then washed and dried at $100^{\circ} \mathrm{C}$ until a black powder was formed.

\subsection{Characterization of AC Adsorbent}

The physical and chemical properties of the produced AC were characterized using XRD, BET, FESEM, and FTIR. The crystalline structure of the $\mathrm{AC}$ was evaluated by X-ray diffraction (XRD) in the range of $2 \theta$ of $10-80^{\circ}$ with $\mathrm{Cu}-\mathrm{K} \alpha$ radiation $(\lambda=1.5405 \AA)$. The specific surface area, pore volume, and pore diameter of $\mathrm{AC}$ were measured at $77 \mathrm{~K}$ using AUTOSORB-1 model AS1 MP-LP instrument. The surface morphology of the AC was viewed by field emission scanning electron microscope (FESEM), JEOL/JSM-7800F with accelerating voltage employed to be in the range of $5-15 \mathrm{kV}$. The IR spectra of the AC adsorbent was measured on Perkin-Elmer System 2000 spectrometer using the $\mathrm{KBr}$ disk method over the range of $2000-400 \mathrm{~cm}^{-1}$.

\subsection{Batch Adsorption Study of 2-Chlorophenol}

The equilibrium adsorption was studied by using batch mode adsorption. A constant mass of adsorbent of $0.1 \mathrm{~g}$ was contacted with $50 \mathrm{~mL}$ of 2-CP solutions of $10 \mathrm{mg} . \mathrm{L}^{-1}$. The flasks were then sealed properly and placed in an incuba- 
tion shaker for further adsorption process. Samples were taken every 5 min until an equilibrium reaction was achieved, in which at this condition, the removal of 2-chlorophenol was complete. The sample was filtered through 0.22 $\mathrm{m}$ syringe filter and diluted to the desired concentration for analysis. Similar adsorption procedure was repeated by varying the initial $\mathrm{pH}$ of 2 -CP solution (3, 5, 7, and 10) and adsorbent dosage $(0.05,0.1,0.3$, and 0.5$) \mathrm{g}$.

\subsection{Analysis of 2-Chlorophenol}

The removal of 2-CP was analysed using Varian Cary 1E UV-Vis spectrophotometer, in which the wavelength of $2-\mathrm{CP}$ is $284 \mathrm{~nm}$. The percentage removals $(\% \mathrm{R})$ of 2 -chlorophenol by $\mathrm{AC}$ adsorbent was calculated using Equation (1).

$$
C P_{S} \text { removal }=\frac{C_{O^{-}} C_{e}}{C_{O}} \times 100 \%
$$

where $C_{o}$ and $C_{e}$ are the concentrations of liquid-phase at initial and equilibrium states (mg.L $\left.{ }^{-1}\right)$, respectively. The equilibrium amount of $C P_{S}$ adsorbed per unit mass of adsorbent, $q_{e}$ (mg.g-1), at different 2-CP concentrations was identified using Equation (2)

$$
q_{e}=\frac{\left(C_{O^{-}} C_{e}\right) V(l)}{W(g)}
$$

where $q_{e}\left(\mathrm{mg}^{\mathrm{g}} \mathrm{g}^{-1}\right)$ is the adsorbate equilibrium amount (CPs) per unit mass of adsorbent (AC); $V$ is the volume of the solution (liter) and $W$ is the mass of the adsorbent (gram).

\section{Results and Discussion}

\subsection{Characterization of AC}

Figure 2 shows the XRD pattern for the AC adsorbent produced from waste tyre. The result indicates the presence of two peaks at $2 \theta$ of 25.43 and $43.89^{\circ}$. The peaks pattern indicates the presence of an amorphous carbon caused by disordered stacked of carbon ring [12].

Table 1. Properties of AC

\begin{tabular}{lc}
\hline \multicolumn{1}{c}{ Parameters } & Value \\
\hline BET surface area $\left(\mathrm{m}^{2} \cdot \mathrm{g}^{-1}\right)$ & 208 \\
Pore volume $\left(\mathrm{cm}^{3} \cdot \mathrm{g}^{-1}\right)$ & 0.5817 \\
Average pore diameter $(\AA)$ & 126 \\
Mesopore volume $\left(\mathrm{cm}^{3} \cdot \mathrm{g}^{-1}\right)$ & 0.5611 \\
Micropore volume $\left(\mathrm{cm}^{3} \cdot \mathrm{g}^{-1}\right)$ & 0.0206 \\
\hline
\end{tabular}

The isotherms produced by $\mathrm{AC}$ showed in Figure 3 was corresponding to type IV adsorption characteristics $[4,12]$. Table 1 summarizes the properties of $\mathrm{AC}$ produced from waste tyre. The results show the adsorbent possessed a high surface area of $208 \mathrm{~m}^{2} \cdot \mathrm{g}^{-1}$ and total pore volume of $0.5817 \mathrm{~cm}^{3} \cdot \mathrm{g}^{-1}$ with most of the pores in the meso-range. These positive results were most probably due to the activation temperature of $900{ }^{\circ} \mathrm{C}$ that were used during pyrolysis process. At $900{ }^{\circ} \mathrm{C}$, more energy is being supplied for the reaction of steam-carbon, which would create new pores and enhance the enlargement of existing pores. This situation leads to the development of more mesopores rather than micropores. Pejman et al. [13] reported that different surface area of activated carbon was correlated with the lower temperature

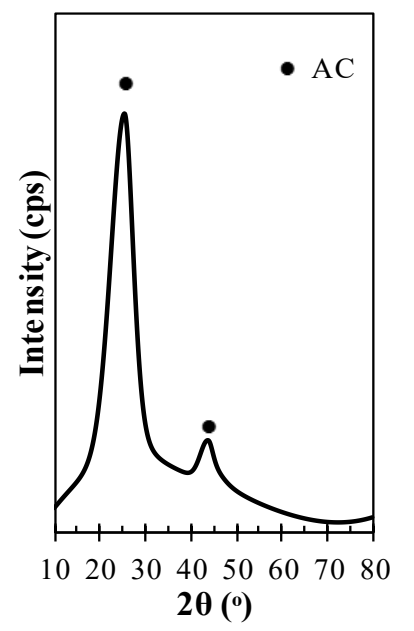

Figure 2. XRD analysis of $\mathrm{AC}$

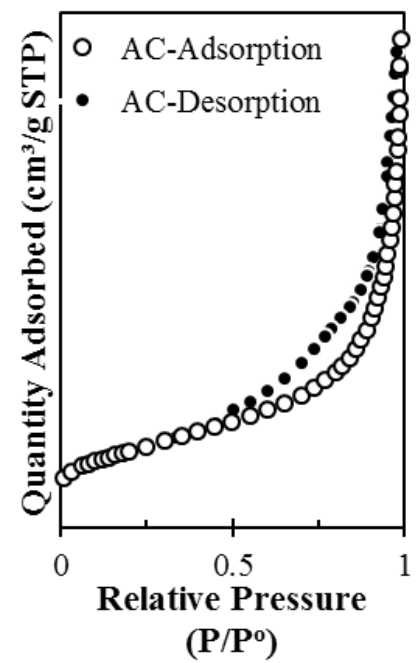

Figure 3. $\mathrm{N}_{2}$ adsorption-desorption isotherm for $\mathrm{AC}$ 


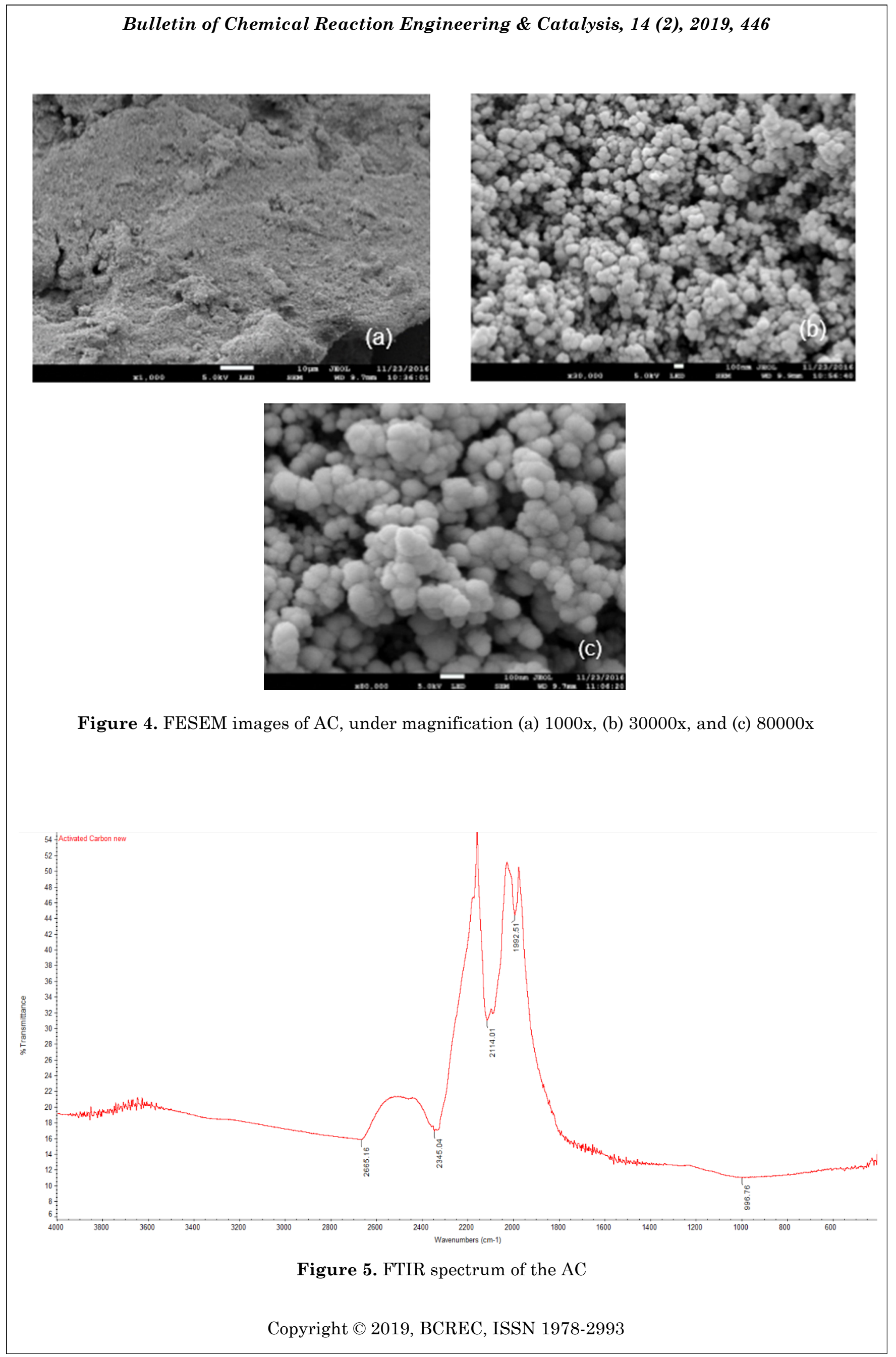


of pyrolysis. Pyrolysis temperature lower than $900{ }^{\circ} \mathrm{C}$ tends to produce carbonaceous materials with lower surface area $\left(<70 \mathrm{~m}^{2} \cdot \mathrm{g}^{-1}\right)$ and total pore volume of $0.20 \mathrm{~cm}^{3} \cdot \mathrm{g}^{-1}[13,14]$. High surface area of AC produced from waste tyre is believed to act as an efficient adsorbent for treatment of pollutant in waste water as its can increase the adsorption capacity.

The surface morphology of the produced AC was shown in Figure 4. The result displays the porous structure of AC with granular morphology. Figure 3 (b) clearly shows the uniform size of the morphology which was formed by agglomeration of AC particles. This morphology might lead to a high surface area and pore volume of the material.

FTIR spectroscopy is an analytical tool for qualitatively determine the chemical changes and functional group of the adsorbent, and the common wavelength present in $\mathrm{AC}$ associate to specific functional group is summarized in Table 2 .

Table 2. Functional group according to wavenumber [15-17]

\begin{tabular}{cc}
\hline Wavenumber $\left(\mathrm{cm}^{-1}\right)$ & Functional Group \\
\hline $1030-1155$ & $\mathrm{C}-\mathrm{O}$ \\
$1550-1650$ & $\mathrm{NH}_{2}$ \\
$600-400$ & Aromatic ring \\
$2500-3500$ & $\mathrm{O}-\mathrm{H}$ \\
$2880-2500$ & $\mathrm{C}-\mathrm{H}$ \\
$3300-3500$ & $\mathrm{~N}-\mathrm{H}$ \\
\hline
\end{tabular}

Figure 5 shows the FTIR spectra of synthesized AC from waste tyre. A wide transmittance band was observed at $3200-3600 \mathrm{~cm}^{-1}$ with a maximum band at $3440 \mathrm{~cm}^{-1}$ [15]. This band can be attributed to the $\mathrm{O}-\mathrm{H}$ stretching vibration which was due to the surface of hydroxyl groups and chemisorbed water. The peaks at $2345 \mathrm{~cm}^{-1}$ and $2665 \mathrm{~cm}^{-1}$ indicate the strong bonded functional group of $\mathrm{O}-\mathrm{H}$ and $\mathrm{C}-\mathrm{H}$ stretching absorption, respectively. The band centered on $1992 \mathrm{~cm}^{-1}$ indicates the presence of aromatic $\mathrm{C}=\mathrm{C}$ groups (carbonization), which proved the presence of carbonization processes during the $\mathrm{AC}$ synthesis. While, the peak at $997 \mathrm{~cm}^{-1}$ represents $\mathrm{C}-\mathrm{O}$ stretching functional group $[16,17]$. Fingerprint region occurs towards the end. Fingerprint region is the region consists of absorptions due to all other single bonds (except H-Z), making it often a complex region that is very difficult to analyze.

\subsection{Adsorption Study on AC}

\subsubsection{Effect of initial 2-CP concentration}

The effect of different initial concentration of 2-CP on the adsorption capacity of AC is illustrated in Figure 6. The highest adsorption performance was achieved at $10 \mathrm{ppm}\left(\mathrm{mg} . \mathrm{L}^{-1}\right)$ with $0.1 \mathrm{~g}$ of adsorbent dosage. The adsorption process of chlorinated hydrocarbons was rapidly increased at initial time of $10 \mathrm{~min}$ due to high availability of vacant active sites with large specific surface area and total pore volume of AC. However, the adsorption rate reduced after $10 \mathrm{~min}$ until an equilibrium state was achieved. This was correlated with the slower internal diffusion process as the repulsive forces of solute molecules with AC surfaces

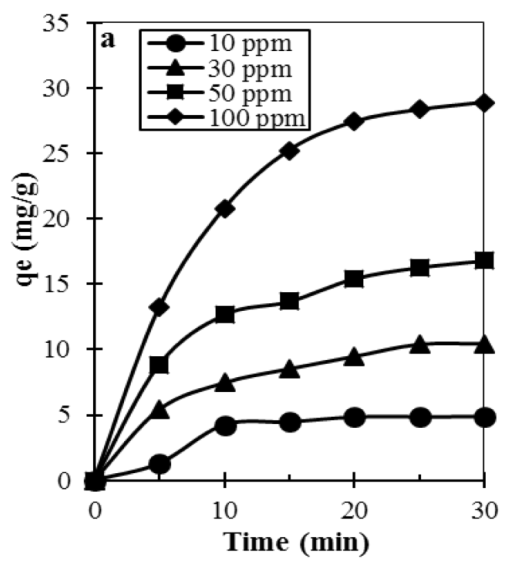

Figure 6. Effect of contact time on adsorption at different initial concentrations

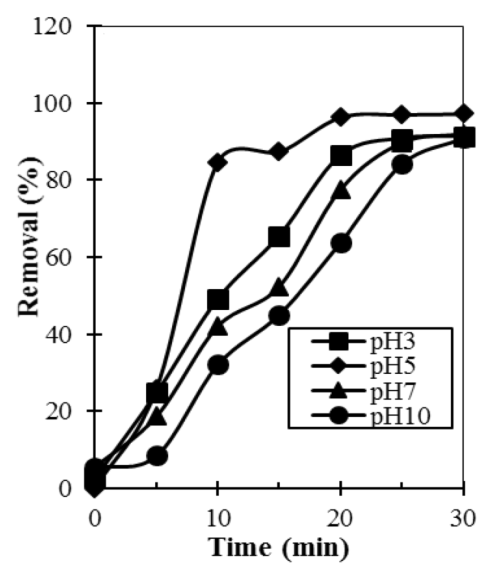

Figure 7. Effect of $\mathrm{pH}$ on removal 2-CP

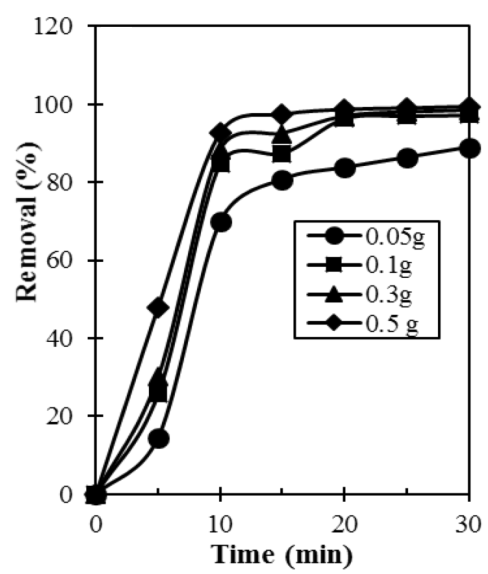

Figure 8. Effect of adsorbent dosage on removal of 2-CP 
in bulk phases became slower [18,19]. Thus, longer contact time is required to reach the equilibrium when high initial concentration was treated. The Langmuir constant, $K_{L}$ for Figure 6 was determined using Langmuir equation: $C e / q_{e}=1 / q_{m} K_{L}+C e / q_{m}$, and the value is $0.067 \mathrm{~L} / \mathrm{mg}$.

\subsubsection{Effect of $\mathrm{pH}$}

Figure 7 indicates the influences of $\mathrm{pH} 3-10$ on adsorption of 2-CP. It is well known that 2$\mathrm{CP}$ is a weak acid, and removal of 2 -CP was associated with the chlorine detached from the phenol aromatic ring [20,21]. The AC removal efficiency towards 2-CP showed a positive behaviour in acidic condition at $\mathrm{pH} 3$ and 5 compared to neutral $(\mathrm{pH}$ 7) and alkali condition ( $\mathrm{pH}$ 10). This was due to the presence of acidic solute molecules in the solution. The location of $\mathrm{AC}$ in acidic solution $(\mathrm{pH}<6)$ makes the outer surface of $\mathrm{AC}$ being surrounded with $\mathrm{H}_{3} \mathrm{O}^{+}$positive charge. In this study, $100 \%$ removal of 2 $\mathrm{CP}$ by $\mathrm{AC}$ were achieved at $\mathrm{pH} 5$ in $30 \mathrm{~min}$. This is due to the presence of $\mathrm{H}_{3} \mathrm{O}^{+}$on $\mathrm{AC}$ surfaces that act as active adsorption sites to interact with 2 -CP molecule. This eventually led to the increase of adsorption capacity which then favoured the removal of 2-CP. While, in basic solution of $\mathrm{pH} 10$, the surface of $\mathrm{AC}$ richest with negative charges of $\mathrm{OH}^{-}$was not effectively reacting with the partial negative charge of 2-CP. This resulted in the decrease in adsorption capacity of 2-CP on $\mathrm{AC}$ adsorbent.

\subsubsection{Effect of AC Adsorbent Dosage}

The effect of AC dosage from 0.05 to $0.5 \mathrm{~g}$ towards removal of 2-CP were shown in Figure 8. At reaction temperature of $25{ }^{\circ} \mathrm{C}$, initial concentration showed $10 \mathrm{mg} . \mathrm{L}^{-1}$ within $30 \mathrm{~min}$ of reaction time, the percent removal of 2 - $\mathrm{CP}$ increased as the adsorbent dosage increased. This was related to the high availability of adsorption active sites when more AC was introduced as adsorbent dosage. Therefore, dosage amount is directly proportional to the adsorption capacity.

\section{Conclusion}

The AC produced from waste tyre in this research work demonstrated the effective performance on removal of chlorine substance from 2-CP. This was associated with its high surface area $\left(208 \mathrm{~m}^{2} \cdot \mathrm{g}^{-1}\right)$ and total pore volume $(0.5817$ $\mathrm{cm}^{3} \mathrm{~g}^{-1}$ ), which was favorable for interaction of chlorine with the $\mathrm{AC}$ active sites during adsorption process. Adsorption studies showed the rapid chlorine adsorption with almost $100 \%$ removal over $0.5 \mathrm{~g} \mathrm{AC}$ was achieved at initial 2-Cp concentration $10 \mathrm{ppm}$ and $\mathrm{pH} 5$ within 10 min of contact time.

\section{Acknowledgments}

The authors express their gratitude to the Universiti Malaysia Pahang for the support under the internal research grant (RDU170330 and RDU1803184).

\section{References}

[1] Yagub, M.T., Sen, T.K., Afroze, S., Ang, H.M. (2014). Dye and its removal from aqueous solution by adsorption: A review. Adv. Colloid Interface Sci., 209: 172-184.

[2] Foo, K.Y. (2018). Effect of microwave regeneration on the textural network, surface chemistry and adsorptive property of the agricultural waste based activated carbons. Process Saf. Environ. Prot., 116: 461-467.

[3] Jardines, M.M., Hernandez, S.M., Texier, A.C., Lopez, F.C. (2018). 2-Chlorophenol consumption by cometabolism in nitrifying SBR Reactors. Chemosphere 212: 41-49

[4] Soltani, T., Lee, B.K. (2016). Mechanism of highly efficient adsorption of 2-chlorophenol onto ultrasonic graphene materials: Comparison and equilibrium. J. Colloid Interface Sci., 481: 168-180.

[5] Chaliha, S., Bhattacharyya, K.G. (2008). Catalytic wet oxidation of 2-chlorophenol,2,4dichlorophenol and 2,4,6-trichlorophenol in water with Mn(II)-MCM41. Chem. Eng. J., 139: $575-588$.

[6] Dobaradaran, S., Nodehi, R.N., Yaghmaeian, K. Jaafari, J., Niari, M.H., Bharti, A.K., Agarwal, S., Gupta, V.K., Azari, A., Shariatifar, N. (2018). Catalytic decomposition of 2-chlorophenol using an ultrasonic-assisted $\mathrm{Fe}_{3} \mathrm{O}_{4}-\mathrm{TiO}_{2} @ M W C N T$ system: Influence factors, pathway and mechanism study. J. Colloid Interface Sci., 512: 172-189.

[7] Lim, J.W., Lim, P.E., Seng, C.E., Adnan, R. (2013) Simultaneous 4-chlorophenol and nitrogen removal in moving bed sequencing batch reactors packed with polyurethane foam cubes of various sizes. Bioresour. Technol., 129: 485-494.

[8] Gupta, N., Kushwaha, A.K., Chattopadhyaya, M.C. (2012). Adsorption studies of cationic dyes onto Ashoka (Saraca asoca) leaf powder. J. Taiwan Inst. Chem. Eng., 43: 604-613.

[9] Blanco, P.H., Wu, C., Williams, P.T. (2014). ScienceDirect Influence of $\mathrm{Ni} / \mathrm{SiO}_{2}$ catalyst preparation methods on hydrogen production from the pyrolysis / reforming of refuse de- 
rived fuel. Int. J. Hydrogen Energy. 39: 57235732 .

[10] Allaboun, H., Abu, Al-Rub, F.A. (2016). Removal of 4-chlorophenol from contaminated water using activated carbon from dried date pits: Equilibrium, kinetics, and thermodynamics analyses. Materials (Basel), 9: 166180.

[11] Al-Rahbi, A.S., Williams, P.T. (2016). Production of activated carbons from waste tyres for lowfile: Waste Manag., 49: 188-195.

[12] Ganiyu, S.A., Alhooshani, K., Sulaiman, K.O., Qamaruddin, M., Bakare, I.A., Tanimu, A., Saleh, T.A. (2016). Influence of aluminium impregnation on activated carbon for enhanced desulfurization of DBT at ambient temperature: Role of surface acidity and textural properties. Chem. Eng. J., 303: 489-500.

[13] Pejman, H., Kit, Y.Y., Jiaxin, G., Huaimin, W., Gordon, M.K. (2016). Sustainable development of tyre char-based activated carbons with different textural properties for valueadded applications. J. Env. Manag., 170: 1-7.

[14] Abaide, E.R., Anchieta, C.G., Foletto, V.S., Reinehr, B., Nunes, L.F., Kuhn, R.C., Mazutti, M.A., Foletto, E.L., Abaide, E.R., Anchieta, C.G., Foletto, V.S., Reinehr, B., Nunes, L.F., Kuhn, R.C., Mazutti, M.A., Foletto, E.L. (2015). Production of Copper and Cobalt Aluminate Spinels and Their Application As Supports for Inulinase Immobilization. Mater. Res., 18: 1062-1069.

[15] Yakout, S.M., Sharaf, El-Deen. G. (2016). Characterization of activated carbon prepared by phosphoric acid activation of olive stones. Arab. J. Chem., 9: S1155-S1162.
[16] He, X., Wu, Z., Sun, Z., Wei, X., Wu, Z., Ge, X., Cravotto, G. (2018). A novel hybrid of Bcyclodextrin grafted onto activated carbon for rapid adsorption of naphthalene from aqueous solution. J. Mol.. Liq., 255:160-167.

[17] Begum, S., Ahmaruzzaman, M. (2018). Green Synthesis of $\mathrm{SnO}_{2}$ Nanoparticles loaded on Activated Carbon and its Application as Photocalayst in the Degradation of Alizarin Red S Dye. Mater. Today Proc., 5: 2314-2320.

[18] Dil, E.A., Ghaedi, M., Asfaram, A., Hajati, S., Mehrabi, F., Goudarzi, A. (2017). Preparation of nanomaterials for the ultrasound-enhanced removal of $\mathrm{Pb}^{2+}$ ions and malachite green dye: Chemometric optimization and modeling. $\mathrm{Ul}$ trason. Sonochem. 34: 677-691

[19] Gialamouidis, D., Mitrakas, M., LiakopoulouKyriakides, M. (2010). Equilibrium, thermodynamic and kinetic studies on biosorption of $\mathrm{Mn}(\mathrm{II})$ from aqueous solution by Pseudomonas sp., Staphylococcus xylosus and Blakeslea trispora cells. J. Hazard. Mater. 182: $672-680$

[20] Kudo, A., Omori, K., Kato, H. (1999). A nove.l aqueous process for preparation of crystal form-controlled and highly crystalline $\mathrm{BiVO}_{4}$ powder from layered vanadates at room temperature and its photocatalytic and photophysical properties. J. Am. Chem. Soc., 121: 11459-11467

[21] Fulazzaky, M.A., Khamidun, M.H., Din, M.F. M., Yusoff, A.R.M. (2014). Adsorption of phosphate from domestic wastewater treatment plant effluent onto the laterites in a hydrodynamic column. Chem. Eng. J., 258: 10-17.

Selected and Revised Papers from The $4^{\text {th }}$ International Conference of Chemical Engineering $\&$ Industrial Biotechnology (ICCEIB 2018) (http://icceib.ump.edu.my/index.php/en/) (Universiti Malaysia Pahang, by 1st_2nd August 2018) after Peer-reviewed by Scientific Committee of ICCEIB 2018 and Peer-Reviewers of Bulletin of Chemical Reaction Engineering \& Catalysis 